\title{
Effect of Fluoride on Endocytosis and Surface Marker Expression Levels of Mouse B Cells In Vitro
}

\author{
Haili Ma ${ }^{\mathrm{a}}$ Zeyu Shi ${ }^{\mathrm{b}}$ Yaoze Dong ${ }^{\mathrm{b}}$ Rui Liang ${ }^{\mathrm{b}}$ Jianshan Chen ${ }^{\mathrm{b}}$ Jinming Wang ${ }^{\mathrm{a}}$ \\ Jundong Wang ${ }^{\text {a }}$
}

aShanxi Key Laboratory of Ecological Animal Science and Environmental Medicine, Shanxi Agricultural University, Taigu, ${ }^{b}$ College of Animal Science and Veterinary Medicine, Shanxi Agricultural University, Taigu, PR China

\section{Key Words}

Fluoride $\cdot$ B cell $\bullet$ Endocytosis $\cdot C D$

\begin{abstract}
Background/Aims: To clarify the effect of fluoride on splenic B cells, the endocytosis and surface marker expression levels of mouse splenic B cells were detected in vitro by flow cytometry. Methods: Cells were stimulated with $10 \mu \mathrm{g} / \mathrm{mL}$ lipopolysaccharide (LPS) and varying concentrations of Sodium Fluoride (NaF) $(0,50 \mu \mathrm{M}, 100 \mu \mathrm{M}, 500 \mu \mathrm{M}, 1000 \mu \mathrm{M})$. Results: The results demonstrated that the endocytic capacity of $\mathrm{B}$ cells was enhanced by $\mathrm{NaF}$ at $50 \mu \mathrm{M}$. NaF significantly enhanced CD80 expression at $50 \mu \mathrm{M}$ and decreased CD86 expression at $500 \mu \mathrm{M}$. CD40 and CD138 expression on B cells were down-regulated at varying high concentrations of NaF. Conclusion: our results showed that the endocytic capacity, expression levels of CD40 and CD80 of B cells changed significantly at lower concentrations, whereas expression levels of CD138 and CD86 changed significantly at higher concentrations, suggesting that fluoride could inhibit immune function in animals.
\end{abstract}

(C) 2016 The Author(s)

Published by S. Karger AG, Basel

\section{Introduction}

As is well known, fluoride (F) primarily has a negative effect on bones and teeth due to clinical skeletal fluorosis and dental fluorosis. Then furthermore epidemiological researches and experimental studies show that it also affects the nervous system [1, 2], reproductive system [3, 4], cardiovascular system [5, 6], immune system [7-9], and so on. Our previous studies showed that excessive fluoride ingestion induced pathological changes in the spleen and impairment of immune function in rabbits $[10,11]$ and thymus apoptosis in female rats [12]. Extravasation of circulating lymphocytes into lymphoid and extra-lymphoid tissue is essential in normal immune surveillance and inflammation [13]. However, the underlying mechanisms of the F-induced damage to the immune system are unclear.

H. Ma and Z. Shi contributed equally to this work. 


\section{Cellular Physiology Cell Physiol Biochem 2016;39:596-603 \begin{tabular}{l|l|l|} 
DOI: 10.1159/000445651 & $\begin{array}{l}\text { C) 2016 The Author(s). Published by S. Karger AG, Basel } \\
\text { www.karger.com/cpb }\end{array}$
\end{tabular} \\ Ma et al.: Fluoride on Endocytosis \& Surface Marker Expression in B Cells}

B cells are not only a major component of the innate immunity but also the main executors in the humoral immunity. B cells are a class of professional antigen presenting cells that deliver antigen to $\mathrm{CD} 4^{+} \mathrm{T}$ cells, a process termed antigen presentation. B cells can capture and present antigens derived from invading microorganisms. However, it is necessary that $B$ cells efficiently bind and internalize soluble antigens that bind specifically to their unique surface immunoglobulins. The capturing, processing, and presenting of soluble antigen to $\mathrm{CD} 4^{+} \mathrm{T}$ cells is an important process of humoral immunity. Little attention has been paid to the effect of fluoride on endocytosis of B cells even though it is the first step to capture the antigen and initiate the humoral immune response.

CD molecules are the general term for a class of differentiation antigens that are located on the cell surface [14]. They not only can be used as surface markers for cell separation and identification, but also are widely involved in cell growth, maturation, differentiation, development and migration. They play important roles in the identification, activation and effectors phase of the immune response [15]. For example, CD86 (B7-2) and CD80 (B7-1) on B cells provide costimulatory signals to T cells [16]; CD40 on B cells is involved in B cell growth and differentiation, and participates in B cell-T cell interactions [15]; and CD138 is the major surface marker of the plasma cells and is one of the key indicators to measure plasma cell differentiation $[17,18]$.

With regard to the effect of fluoride on the humoral immune response, previous studies have mostly concentrated on the production of immunoglobulin. Little research has been done on the antibody-producing cells, namely B cells. In this study, we attempted to clarify the mechanisms of fluoride on the innate immune response and the adaptive immune response. Specifically, we have investigated the effect of fluoride on the endocytosis and surface markers, i.e., CD80, CD86, CD40, and CD138 of mouse splenic B cells.

\section{Materials and Methods}

Mice

Six to eight week-old female Kunming mice were obtained from the Experimental Animal Center of Shanxi Medical University (Taiyuan, China) and housed in conventional housing at the Animal Care facility, Shanxi Agricultural University. Animal experiments were approved by the Animal Care and Use Program of College of Animal Science and Technology and performed according to the guidelines set by the Institutional Animal Care and Use Committee of China.

\section{Antibodies and reagents}

Phycoerythrin (PE)-labelled rat anti-mouse CD45R/B220 (clone: RA3-6B2), fluorescein isothiocyanate (FITC)-conjugated rat anti-mouse CD40 (clone: 3/23), peridinin chlorophyll protein (PerCP-Cy ${ }^{\mathrm{TM}}$ ) 5.5-conjugated hamster anti-mouse CD80 (clone:16-10A1), fluorescein isothiocyanate (FITC)-conjugated rat anti-mouse CD86 (clone: GL1), and allophycocyanin (APC)-conjugated rat anti-mouse CD138 (clone: 281-2) were purchased from BD Pharmingen ${ }^{\mathrm{TM}}$ (San Diego, USA). Lipopolysaccharide (Escherichia coli serotype 0111:B4) was purchased from Sigma-Aldrich (St Louis, MO). FITC-dextran (Molecular Probes) was purchased from Invitrogen (San Diego, CA). Annexin V/PI apoptosis detection kit was purchased from KeyGEN Biotech (Nanjing, China). PI and RNase A were purchased from Solarbio (Beijing, China). Fetal bovine serum (FBS) was purchased from Hangzhou Sijiqing Biological Engineering Material Company (Hangzhou, China). Analytical grade NaF was purchased from Jiangbei chemical reagent factory (Wuhan, China).

Mice splenic lymphocytes preparation and culture

Mouse spleen was aseptically isolated and ground in mouse lymphocyte separation medium. Murine lymphocytes were isolated and cultured $\left(1 \times 10^{6} /\right.$ well) in 24 -well plates in a final volume of $1000 \mu \mathrm{L}$ RPMI 1640 medium was supplemented with $10 \%$ fetal calf serum, $10 \mu \mathrm{g} / \mathrm{ml} \mathrm{LPS} \mathrm{[19]} \mathrm{and} \mathrm{the} \mathrm{varying} \mathrm{concentrations}$ of $\operatorname{NaF}(0,50 \mu \mathrm{M}, 100 \mu \mathrm{M}, 500 \mu \mathrm{M}$, and $1000 \mu \mathrm{M})$ and incubated at $37^{\circ} \mathrm{C}$ in a $5 \% \mathrm{CO}_{2}$ incubator for $48 \mathrm{hr}$. 


\section{Cellular Physiology Cell Physiol Biochem 2016;39:596-603

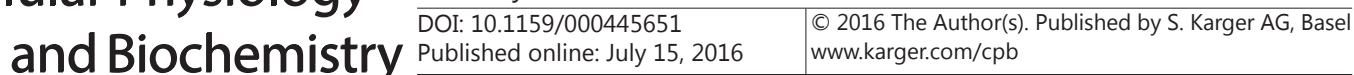 \\ Ma et al.: Fluoride on Endocytosis \& Surface Marker Expression in B Cells}

\section{Endocytosis assay}

After extensive washing, the cultured lymphocytes were resuspended in culture medium and $1 \times 10^{6}$ cells in $0.2 \mathrm{ml}$ culture medium were incubated with $25 \mu \mathrm{g} / \mathrm{ml}$ of FITC-dextrans (Molecular Probes) at $37^{\circ} \mathrm{C}$ for $1 \mathrm{hr}$. Subsequently the cells were washed with flow cytometry staining buffer and were then stained with PE-labeled rat anti-mouse CD45R/B220 at $4{ }^{\circ} \mathrm{C}$ for $30 \mathrm{~min}$ in the dark, the cells were washed twice and resuspended in FACS buffer for flow cytometric analysis [20]. Fluorescence intensity was measured using flow cytometry analyses.

\section{B-cell surface molecule analyses}

The cultured lymphocytes were washed and collected in phosphate-buffered saline (PBS) containing $2 \%$ FCS, and $1 \times 10^{6}$ cells were then stained with PE-labeled rat anti-mouse CD45R/B220 in combination with either FITC-conjugated rat anti-mouse CD40, PerCP-Cy ${ }^{\mathrm{TM}}$ 5.5-labelled hamster anti-mouse CD80, FITC-conjugated rat anti-mouse CD86, APC-conjugated rat anti-mouse CD138 monoclonal antibodies at a concentration recommended by the manufacturer for $30 \mathrm{~min}$ at $4{ }^{\circ} \mathrm{C}$ in the dark. After extensive washing with flow cytometry staining buffer, cells were spun down and resuspended in 0.5 - $1 \mathrm{ml}$ fixing buffer (1\% paraformaldehyde in PBS) for flow cytometry analyses [21,22]. The data were processed with the CellQuest 3.3 software.

\section{Statistical analysis}

Data are shown as mean \pm standard deviation (SD) and analyzed using Student's $t$-test. $P$-values of $<$ 0.05 were considered as significant.

\section{Results}

Effect of sodium fluoride on B cell endocytosis

Endocytosis assay (Fig. 1) showed that NaF-triggered B-cell endocytosis was not obvious at doses of $100 \mu \mathrm{M}, 500 \mu \mathrm{M}, 1000 \mu \mathrm{M}$. However, the endocytosis of B cells was significantly enhanced at the concentrations of $50 \mu \mathrm{M} \mathrm{NaF}$ compared with control groups.

Expression of B cell surface markers $C D$ s stimulated with various doses of sodium fluoride Expression of CD80 on B cells

The results (Fig. 2) showed that there was up-regulation of surface expression of CD80 on B cells at varying concentrations of $\mathrm{NaF}$. At doses of $500 \mu \mathrm{M} \mathrm{NaF}$, expression levels of CD80 on splenic B cells were not detectable. The concentration of $100 \mu \mathrm{M}$ and $1000 \mu \mathrm{M} \mathrm{NaF}$
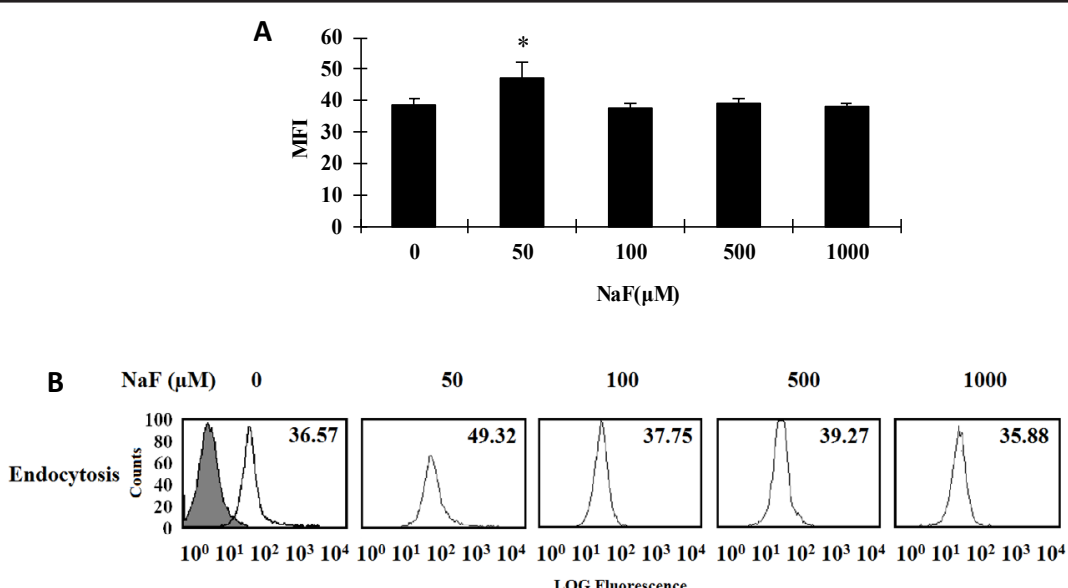

Fig. 1. Endocytosis of mouse splenic B cells induced by varying concentrations of NaF. (A) The results of three independent experiments are depicted with S.E. indicated. $*(p<0.05)$ indicates a significant difference between the control and the group. (B) The numbers inserted in the histogram represents the mean fluorescence intensity (MFI). Filled areas represent the respective isotype controls. These data are representative of three independent experiments. 


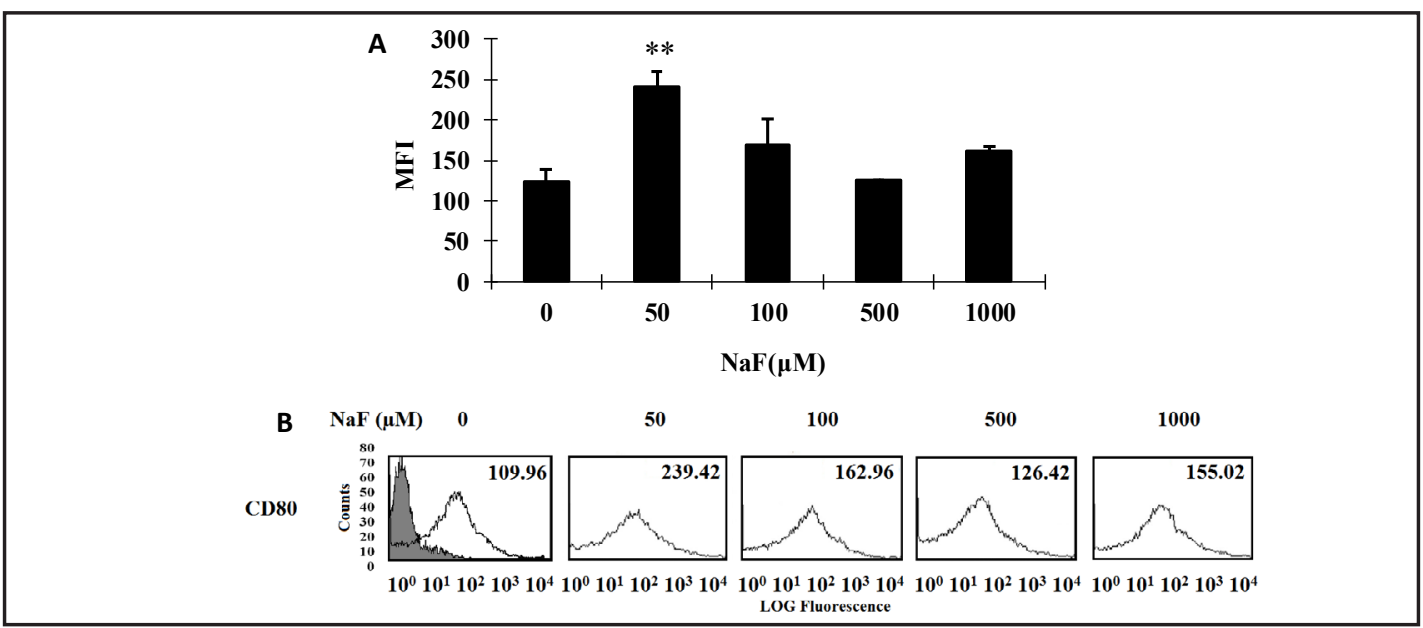

Fig. 2. Expression levels of CD80 on splenic B cells in response to NaF stimulation. (A) The results of three independent experiments are depicted with S.E. indicated. ${ }^{*}(\mathrm{p}<0.01)$ indicates an extremely significant difference between the control and the experimental groups. (B) The numbers inserted in the histogram represents the mean fluorescence intensity (MFI). Filled areas represent the respective isotype controls. These data are representative of three independent experiments.

Fig. 3. Expression levels of CD86 on splenic $\mathrm{B}$ cells in response to NaF stimulation. (A) The results of three independent experiments are depicted with S.E. indicated. ${ }^{* *}$ ( $\left.p<0.01\right)$. (B) The numbers inserted in the histogram represents the mean fluorescence intensity (MFI). Filled areas represent the respective isotype controls. These data are representative of three independent experiments.

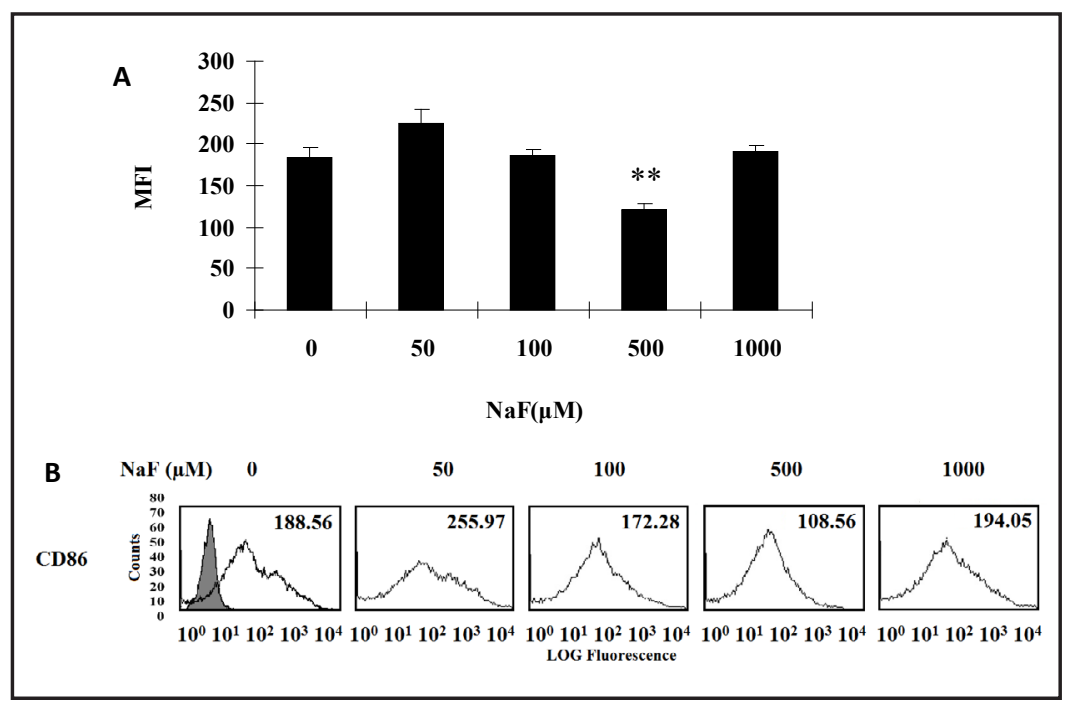

induced only a slight change in expression levels. In contrast, there was significant difference in expression levels of CD80 on B cells between the control and $50 \mu \mathrm{M}$ groups.

\section{Expression of CD86 on B cells}

As shown in Fig. 3, the expression levels of CD86 on B cells were only slightly increased by treatment with $50 \mu \mathrm{M}, 100 \mu \mathrm{M}$ and $1000 \mu \mathrm{M} \mathrm{NaF}$. However, there was extremely significant down-regulation of expresson levels of CD86 at $500 \mu \mathrm{M}$ compared with control groups.

\section{Expression of CD40 on B cells}

The results (Fig. 4) showed that there was down-regulation of surface expression of $\mathrm{CD} 40$ on B cells at varying concentrations of $\mathrm{NaF}$. The expression levels of CD40 on splenic B cells only slightly decreased by treatment with $500 \mu \mathrm{M}$ and $1000 \mu \mathrm{M} \mathrm{NaF}$ compared with control groups. There was extremely significant down-regulation in expressing levels of CD40 in the $50 \mu \mathrm{M}$ and $100 \mu \mathrm{M}$ groups compared with control groups. 
Fig. 4. Expression levels of CD40 on splenic $B$ cells in response to $\mathrm{NaF}$ stimulation. (A) The results of three independent experiments are depicted with S.E. indicated. $^{* *}$ ( $\left.\mathrm{p}<0.01\right)$. (B) The numbers inserted in the histogram represents the mean fluorescence intensity (MFI). Filled areas represent the respective isotype controls. These data are representative of three independent experiments.

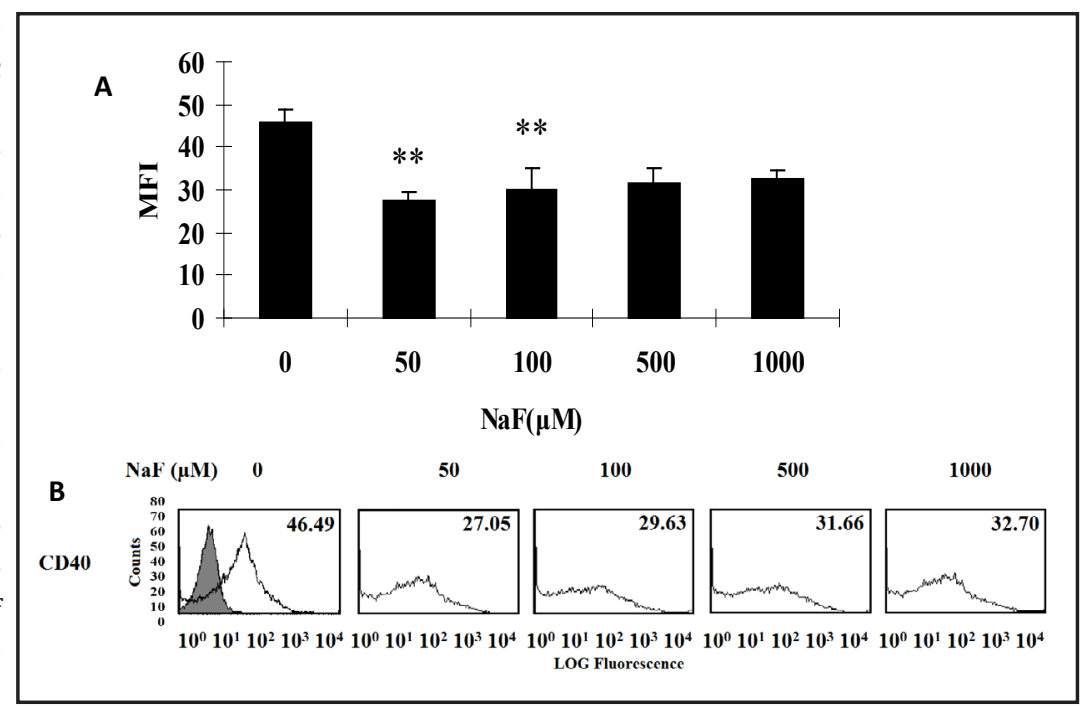

Fig. 5. Expression levels of CD138 on splenic B cells in response to NaF stimulation. (A) The results of three independent experiments are depicted with S.E. indicated. ** ( $p<0.01)$. (B) The numbers inserted in the histogram represents the mean fluorescence intensity (MFI). Filled areas represent the respective isotype controls. These data are representative of three independent experiments.

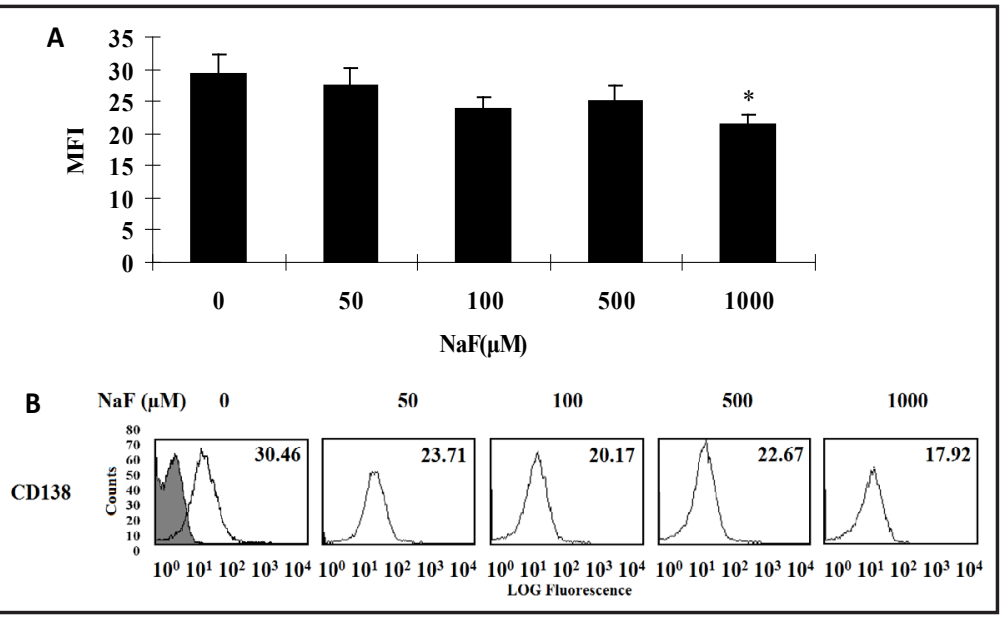

Expression of CD138 on B cells

The results (Fig. 5) showed that there was down-regulation of surface expression of CD138 on B cells at varying concentrations of NaF. The expression levels of CD138 only slightly decreased by treatment with $50 \mu \mathrm{M}, 100 \mu \mathrm{M}$ and $500 \mu \mathrm{M}$ NaF. There was significant down-regulation in expression levels of CD138 on B cells in the $1000 \mu \mathrm{M}$ group compared with control groups.

\section{Discussion}

B cells are one of the main classes of professional antigen-presenting cells. The presentation function of B cells is extremely important for the production of anti-TD antibody. Endocytosis is essential for antigen presentation by B cells. The endocytosis of many signaling receptors is stimulated by ligand-induced activation [23]. Endocytosis occurs at the cell surface and involves internalization of the plasma membrane along with its constituent membrane proteins and lipids. The experimental results show that the endocytotic ability of B cells was significantly enhanced by $\mathrm{NaF}$ at the concentrations of $50 \mu \mathrm{M}$. A study by Sapna and Arbind [24] found that the sodium fluoride toxicity may increase the phagocytic activity 
of macrophages to engulf more RBC in spleen and to develop anemia. Endocytosis is one of the main components of the innate immune response. Antigen presenting cells are also associated with the adaptive immune response based on this basic function. Endocytosis is only the first step involved in the immune response, and subsequently also relates to a number of steps, such as metastasis, degradation, processing, antigens-presentation. It is not absolutely illustrated that fluoride can reinforce the immune function when endocytosis enhanced by it. However, we found that the endocytotic function of B cells was enhanced significantly only at lower concentrations of NaF. It did not change significantly at higher concentrations. We speculated that this may be related to the cytotoxicity of fluoride. Many studies have shown that the effect of the high concentration of fluoride may cause cell apoptosis, in multiple cell types including hepatocytes [25], human embryo hepatocytes [26], human dental pulp stem cells [27], peripheral blood mononuclear cells [28], and osteoblasts [29]. Thus, we speculated that at higher concentrations of fluoride there may also be induction of B cell apoptosis.

CD80 and CD86 are part of an extensive family of costimulatory molecules critical for T cell activation [16]. CD80 and CD86 have also been shown to differentially regulate B cell activation; wherein CD80 provides an inhibitory signal to B cell function, and CD86 provides a stimulatory signal to B cell function [30]. The CD80/CD86-CD28 pathway has been shown to be bidirectional, whereby signaling by CD80 and CD86 on DCs results in the production of IFN and IL-6 [31]. Studies by de Vos et al. [32] have provided solid evidence that NaF significantly suppressed Con A-induced IFN-gamma production of lymphocytes. Lund et al. [33] have already described that IL-6 was significantly increased in the bronchial portion for those cells exposed to "high" concentrations fluoride. In the present study we demonstrated that NaF promoted prominent expression levels of CD80 at doses of $50 \mu \mathrm{M}$ and that it reduced the expression levels of CD86 at $500 \mu \mathrm{M}$. This prompts the hypothesis that the immune function may be reduced due to the impact of NaF. CD80 and CD86 are potent regulators of IgG secretion by previously activated B cells [34]. Thus, we can speculate that the ability to produce antibodies may be weakened after stimulation by NaF. Jain and Susheela [35] found that fluoride could inhibit the formation of antibody. Our experiments show that the effect of NaF on the expression of CD80 and CD86 has an important role in the humoral immune function. It is mainly embodied in reducing the production of antibody and some types of cytokines.

CD40 is a member of the tumor necrosis factor (TNF) receptor superfamily expressed on antigen-presenting cells, including B cells [36]. The CD40-ligand (CD40-L/CD154), a member of the TNF family, is mainly expressed on activated CD $4^{+} \mathrm{T}$ cells only [37]. Interactions between CD40 and CD40 ligand have been implicated as being critical for the initiation of T-lymphocyte-dependent humoral and cell-mediated immune responses [38]. The cross-linking of CD40 with CD40L induces the production of various cytokines, such as IL-1, IL-8, and TNF [39]. Hosokawa et al. [40] found that the concentrations of TNF $\alpha$ and IL-1 $\beta$ produced by macrophages in the supernatant were significantly lower in $1000 \mu \mathrm{M}$ NaF-exposed group than in the control respectively. Refsnes et al. [41] found that exposure of human epithelial lung cells to fluorides induced a marked increase in the release of IL-8. Our research shows that the expression levels of CD40 on B cells decreased by treatment with varying concentrations of NaF. Therefore, the decrease of CD40 expression may lead to a weakened cellular immune function. CD40 is also a class of important costimulatory molecules involved in B cell activation. Thereby changes of CD40 expression may also reduce the humoral immune function.

CD138 (Syndecan-1), a member of the transmembrane heparan sulfate proteoglycan family, acts as an extracellular matrix receptor [42]. Within the hematopoietic system, CD138 is an excellent marker of plasmacytic differentiation [17]. Expression measurements of the CD138 protein are a quantitative method for determining the degree of B cell differentiation into plasma cell [18]. As antibody-producing cells, reduction in the number of plasma cells can function to reduce antibody production. The antibody is an important immune molecule that mediates humoral immunity and posseses extensive biological functions. Our results

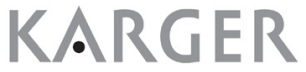




\section{Cellular Physiology Cell Physiol Biochem 2016;39:596-603 \begin{tabular}{l|l|l|} 
and BOI: 10.1159/000445651 & $\begin{array}{l}\text { C) 2016 The Author(s). Published by S. Karger AG, Basel } \\
\text { www.karger.com/cpb }\end{array}$
\end{tabular} \\ Ma et al.: Fluoride on Endocytosis \& Surface Marker Expression in B Cells}

shows that the expression levels of CD138 were reduced at varying concentrations of $\mathrm{NaF}$. This indicates that NaF can directly affect the levels of the humoral immune response. Many previous trials have demonstrated that sodium fluoride can affect antibody formation [35, $43,44]$.

In summary, we discovered that the endocytic capacity and CD80 and CD86 expression levels on B cells were enhanced at lower concentrations of NaF $(\leq 50 \mu \mathrm{M})$; and CD40 and CD138 expression levels on B cells were reduced by varying high concentrations of NaF. Our results suggest that fluoride may play an inhibitory effect on the immune function.

\section{Acknowledgements}

The authors thank Dou Yan for assistance with flow cytometric analysis. This research was sponsored by the China National Natural Science Foundation (Grant No. 31172376; 31001089; 31240009).

\section{Disclosure Statement}

All authors declare that they have no conflict of interest.

\section{References}

1 Ge YM, Niu RY, Zhang JH, Wang JD: Proteomic analysis of brain proteins of rats exposed to high fluoride and low iodine. Arch Toxicol 2011;85:27-33.

2 Wang AG, Xia T, Chu QL, Zhang M, Liu F, Chen XM, Yang KD: Effects of fluoride on lipid peroxidation, DNA damige and apoptosis in human embryo hepatocytes. Biomed Environ Sci 2004;17:217-222.

3 Long H, Jin Y, Lin M, Sun Y, Zhang L, Clinch C: Fluoride toxicity in the male reproductive system. Fluoride 2009;42:260-276.

4 Sun ZL, Niu RY, Wang B, Jiao ZB, Wang JM, Zhang JH, Wang SL, Wang JD: Fluoride-induced apoptosis and gene expression profiling in mice sperm in vivo. Arch Toxicol 2011;85:1441-1452.

5 Ma YQ Niu RY, Sun ZL, Wang JM, Luo GY, Zhang JH, Wang JD: Inflammatory responses induced by fluoride and arsenic at toxic concentration in rabbit aorta. Arch Toxicol 2012;86:849-856.

6 Varol E, Varol S: Effect of fluoride toxicity on cardiovascular systems: role of oxidative stress. Arch Toxicol 2012;86:1627.

7 Chen T, Cui Y, Bai CM, Gong T, Peng X, Cui HM: Increased apoptotic lymphocyte population in the spleen of young chickens fed diets high in fluorine. Fluoride 2009;42:94-100.

8 Machalinska A, Wiszniewska B, Tarasiuk J, Machalinski B: Fluoride 2001;35:231-238.

9 Podder S, Chattopadhyay A, Bhattacharya S, Ray MR: Histopathology and cell cycle alteration in the spleen of mice from low and high doses of sodium fluoride. Fluoride 2010;43:237-245.

10 Zhou BH, Wang HW, Wang JM, Zhang JH, Yan XY, Wang JD: Effects of malnutrition and supplemented nutrition on nonspecific immune function changes induced by fluoride in rabbits. Fluoride 2007;40:169177.

11 Zhou BH, Wang HW, Wang JM, Zhang JH, Yan XY, Wang JD: Effects of malnutrition and supplemented nutrition on specific immune parameter changes induced by fluoride in rabbits. Fluoride 2009;42:216-223.

12 Wang HW, Zhou BH, Cao JL, Gu XL, Cao CF, Wang JD: Effects of dietary protein and calcium on thymus apoptosis induced by fluoride in female rats (Wistar rats). Environ Toxicol 2009;24:218-224.

13 Zhi K, Li M, Zhang X, Gao Z, Bai J, Wu Y, Zhou S, Li M, Qu L. $\alpha 4 \beta 7$ Integrin (LPAM-1) is upregulated at atherosclerotic lesions and is involved in atherosclerosis progression. Cell Physiol Biochem 2014;33:187687.

14 Elghetany MT: Surface antigen changes during normal neutrophilic development: a critical review. Blood Cells Mol Dis 2002;28:260-274.

15 Kenneth M: Janeway's Immunobiology, ed 8. Garland Science, Taylor \& Francis Group, New York, 2012.

16 Rothstein DM, Sayegh MH: T-cell costimulatory pathways in allograft rejection and tolerance. Immunol Rev 2003;196:85-108.

17 O'Connell FP, Pinkus JL, Pinkus GS: CD138 (syndecan-1), a plasma cell marker immunohistochemical profile in hematopoietic and nonhematopoietic neoplasms. Am J Clin Pathol 2004;121:254-263. 


\section{Cellular Physiology Cell Physiol Biochem 2016;39:596-603 \begin{tabular}{l|l} 
and Biochemistry & $\begin{array}{l}\text { DOI: 10.1159/000445651 } 216 \\
\text { Published online: July 15,2016 }\end{array}$ \\
\hline
\end{tabular} \\ Ma et al.: Fluoride on Endocytosis \& Surface Marker Expression in B Cells}

18 Wijdenes J, Vooijs WC, Clément C, Post J, Morard F, Vita N, Laurent P, Sun RX, Klein B, Dore JM: A plasmocyte selective monoclonal antibody (B-B4) recognizes syndecan-1. Br J Haematol 1996;94:318-323.

19 Xu H, Liew LN, Kuo IC, Huang CH, Goh DL, Chua KY: The modulatory effects of lipopolysaccharidestimulated B cells on differential T-cell polarization. Immunology 2008;125:218-228.

20 Schmid E, Xuan NT, Zahir N, Russo A, Yang W, Kuhl D, Faggio C, Shumilina E, Lang F. Serum- and glucocorticoid-inducible kinase 1 sensitive NF- $\kappa B$ signaling in dendritic cells. Cell Physiol Biochem 2014;34:943-954.

21 Hawley TS, Hawley RG: Methods in Molecular Biology: Flow Cytometry Protocols, ed 2. Hawley and Humana Press Inc. Totowa NJ, 2004.

22 Macey MG: Flow Cytometry Principles and Applications. Humana Press Inc. Totowa, New Jersey, 2007.

23 Alexander S, Mark von Z: Endocytosis and signaling: intertwining molecular networks. Nat Rev Mol Cell Biol 2009;10:609-622.

24 Sapna K, Arbind K: Fluoride toxicity enhances phagocytic activity of macrophages in spleen of rats. Asian J Exp Biol Sci 2011;2:283-287.

25 He LF, Chen JG: DNA damage, apoptosis and cell cycle changes induced by fluoride in rat oral mucosal cells and hepatocytes. World J Gastroenterol 2006;12:1144-1148.

26 Wang JD, Ge YM, Ning HM, Wang SL: Effects of high fluoride and low iodine on biochemical indexes of the brain and learning-memory of offspring rats. Fluoride 2004;37:201-208.

27 Kanjevac T, Milovanovic M, Volarevic V, Lukic ML, Arsenijevic N, Markovic D, Zdravkovic N, Tesic Z, Lukic A: Cytotoxic effects of glass ionomer cements on human dental pulp stem cells correlate with fluoride release. Med Chem 2012;8:40-45.

28 Rocha-Amador DO, Calderón J, Carrizales L, Costilla-Salazar R, Pérez-Maldonado IN: Apoptosis of peripheral blood mononuclear cells in children exposed to arsenic and fluoride. Environ Toxicol Pharmacol 2011;32:399-405.

29 Yan XY, Yan XT, Alex M, Han TL, Chen QL, Li J, Wang JD: Fluoride induces apoptosis and alters collagen I expression in rat osteoblasts. Toxicol Lett 2011;200:133-138.

30 Suvas S, Singh V, Sahdev S, Vohra H, Agrewala JN: Distinct role of CD80 and CD86 in the regulation of the activation of B cell and B cell lymphoma. J Biol Chem 2002;277:7766-7775.

31 Orabona C, Grohmann U, Belladonna ML, Fallarino F, Vacca C, Bianchi R, Bozza S, Volpi C, Salomon BL, Fioretti MC, Romani L, Puccetti P: CD28 induces immunostimulatory signals in dendritic cells via CD80 and CD86. Nat Immunol 2004;5:1134-1142.

32 de Vos G, Jerschow E, Liao Z, Rosenstreich D: Effects of fluoride and mercury on human cytokine response in vitro. J Allergy Clin Immunol 2004;113:S66.

33 Lund K, Refsnes M, Sandstrøm T, Søstrand P, Schwarze P, Boe J, Kongerud J: Increased CD3 positive cells in bronchoalveolar lavage fluid after hydrogen fluoride inhalation. Scand J Work Environ Health 1999;25:326334.

34 Rau FC, Dieter J, Luo Z, Priest SO, Baumgarth N: B7-1/2 (CD80/CD86) direct signaling to B cells enhances IgG secretion. J Immunol 2009;183:7661-7671.

35 Jain SK, Susheela AK: Effect of sodium fluoride on antibody formation in rabbits. Environ Res 1987;44:117125.

36 Carlring J, Szabo MJ, Dickinson R, De Leenheer E, Heath AW: Conjugation of lymphoma idiotype to CD40 antibody enhances lymphoma vaccine immunogenicity and antitumor effects in mice. Blood 2012;119:2056-2065.

37 van Kooten C, Banchereau J: CD40-CD40 ligand. J Leukoc Biol 2000;67:2-17.

38 Noelle RJ: CD40 and its ligand in host defense. Immunity 1996;4:415-419.

39 Hashimoto N, Kawabe T, Imaizumi K, Hara T, Okamoto M, Kojima K, Shimokata K, Hasegawa Y: CD40 plays a crucial role in lipopolysaccharide-induced acute lung injury. Am J Respir Cell Mol Biol 2004;30:808-815.

40 Hosokawa M, Sugaya C, Inoue Y, Tsunoda M, Aizawa Y: Cytotoxicity and inhibition of TNF $\alpha$ and interleukin$1 \beta$ by fluoride in the J774.1 murine macrophage cell line. Fluoride 2009;42:188-197.

41 Refsnes M, Thrane EV, Låg M, Thoresen GH, Schwarze PE: Mechanisms in fluoride-induced interleukin-8 synthesis in human lung epithelial cells. Toxicology 2001;167:145-158.

42 Elenius K, Salmivirta M, Inki P, Mali M, Jalkanen M: Binding of human syndecan to extracellular matrix proteins. J Biol Chem 1990;265:17837-17843.

43 Song S, Zhang M: Preliminary study of the humoral immune toxicity of fluoride. Environ Health Magazine 1990;2:61-62.

44 Zhang J, He L: The impact of chronic fluorosis on rats' immune function. Proc Xi'an Med University 1995;1:26-29. 